\title{
Study of socio-demographic factors in cases of pregnancy induced hypertension and its associated risk factors in a tertiary care hospital
}

\author{
Radheshyam Bairwa, Shikha Mandve*, Savitri Sharma
}

Department of Obstetrics and Gynecology, Jhalawar Medical College, Rajasthan, India

Received: 04 March 2020

Accepted: 16 March 2020

*Correspondence:

Dr. Shikha Mandve,

E-mail: shiks008@gmail.com

Copyright: () the author(s), publisher and licensee Medip Academy. This is an open-access article distributed under the terms of the Creative Commons Attribution Non-Commercial License, which permits unrestricted non-commercial use, distribution, and reproduction in any medium, provided the original work is properly cited.

\begin{abstract}
Background: The aim of the study was to study the socio-demographic factors in cases of pregnancy induced hypertension and its associated risk factors in a tertiary care hospital.

Methods: The present retrospective study was conducted in the obstetrics and gynecology department of Shrimati Heera Kunwar Baa Memorial Hospital, Jhalawar, Rajasthan from December 2018 to November 2019. A total of 80 cases of pregnant women with PIH were studied. The socio-demographic data like age, parity, gestational age of presentation, mode of delivery, maternal and perinatal complications were noted from the hospital records and studied.

Results: The incidence of PIH was found to be $8.16 \%$ in pregnant women attending the SHKBM Hospital. Majority of the study subjects were rural dweller (70\%). A higher incidence of PIH was found among illiterate women $(51.25 \%) .53 .75 \%$ cases were in the age group of 25-30 years and 25\% were in the age group of 19-24 years. In the present study, incidence of PIH was found to be highest among primigravidas $(67.50 \%)$ as compared to multigravidas $(32.5 \%)$. Most cases were delivered by caesarean section $(73.75 \%)$ and $26.25 \%$ were delivered vaginally. Out of 80 cases, $16.25 \%$ of cases were complicated by eclampsia, Severe PIH in $12.5 \%$, abruptio placentae in $2.5 \%$ and HELLP Syndrome in $1.25 \%$ cases.

Conclusions: PIH is a very common complication encountered in pregnancy associated with adverse maternal and fetal outcome. The risk is higher among young primigravidas and in rural population. Better health care facilities and awareness among the pregnant women will help in reducing the incidence of PIH and its associated complications.
\end{abstract}

Keywords: Eclampsia, Gestational age, Pregnancy induced hypertension, Primigravida

\section{INTRODUCTION}

Pregnancy induced hypertension is a common complication we encounter in pregnancy. It is associated with adverse fetal, neonatal and maternal outcome. ${ }^{1}$ It consists of a group of disorders that develops due to gravid state after 20 weeks of pregnancy. It consists of gestational hypertension with blood pressure > 140/90 $\mathrm{mmHg}$ without proteinuria, preeclampsia which is gestational hypertension with proteinuria and eclampsia which is preeclampsia with convulsions. The features of hypertension usually resolve to normal within 6-12 weeks of delivery. ${ }^{2,3}$ Pregnancy induced hypertension is the most frequent cause of hypertension during pregnancy, constituting of about $70 \% .^{4}$

The incidence of pre-eclampsia in nulliparous population ranges from 3 to 10 per cent worldwide. ${ }^{5}$ Incidence of eclampsia in the developed countries is about 1 in 2000 deliveries as compared to developing countries where it varies from 1 in 100 to 1 in $1700 .^{6-9}$ The national incidence of PIH is $15.2 \%$ in India, while it is four times higher in primipara women than in multipara. ${ }^{10,11} 13 \%$ of the maternal deaths are in the women with pregnancy induced hypertension and eclampsia, the most terrible form that accounts for major cause of death. ${ }^{12}$ The high 
incidence observed has pointed towards poverty, lack of education and unawareness regarding health care in this part of the world.

Till now, despite the number of studies on hypertensive disorders of pregnancy, the aetiology remains unclear. The speculated aetiologies that play important role in development of PIH include abnormal placentation, vasculopathy, inflammatory changes, genetic, nutritional and immunologic factors. ${ }^{13}$

$\mathrm{PIH}$ is more commonly seen in women with younger age, elderly pregnant women, primiparous, obese women, women with multiple pregnancies and molar pregnancy. History of PIH in previous pregnancy is an important risk factor for developing PIH in subsequent pregnancy. Family history of PIH is also a risk factor for development of PIH. ${ }^{14}$

A prompt and early diagnosis is essential as pregnancies associated with hypertensive disorders are often associated with adverse maternal and fetal complications. The risks associated are IUGR, preterm birth, antepartum and postpartum haemorrhage, perinatal death and maternal death. ${ }^{14}$

The present work was conducted to study the sociodemographic profile and to find out the risk factors among antenatal mothers with pregnancy induced hypertension.

\section{METHODS}

This study is to be carried out as retrospective observational study. The study is to be carried out in Department of obstetrics and gynecology, SHKBM hospital, Jhalawar, Rajasthan, India

\section{Inclusion criteria}

- All pregnant women with PIH admitted in obstetrics ward with gestational age greater than 28 weeks.

\section{Exclusion criteria}

- Pregnant patients developing PIH before 28 Weeks, with history of chronic hypertension, renal diseases, coronary heart disease, diabetes mellitus

- Pregnant women with smoking and alcohol habits

- Patients with incomplete data.

\section{Patient data relevant to the study will be obtained from following sources}

- Case sheet

- Antenatal visit record.

PIH was defined as blood pressure $>140 / 90 \mathrm{mmHg}$ with or without proteinuria and/or edema after 20 weeks of gestation.
The medical records had details regarding patients demographic data, age, diagnosis, gestational age, parity, diagnosis, obstetric history, mode of delivery and maternal and fetal outcome.

Primigravida was defined as first pregnancy. The subsequent pregnancy was called multigravida. Gestational age was calculated from LMP.

\section{Statistical analysis}

The data was analyzed using Graph Pad Prism statistical software version 5.0 .

\section{RESULTS}

During the one-year study, 1020 pregnant women attended the obstetrics and gynaecology department, out of which 80 pregnant women were diagnosed with hypertension. The incidence of PIH was found to be $8.16 \%$.

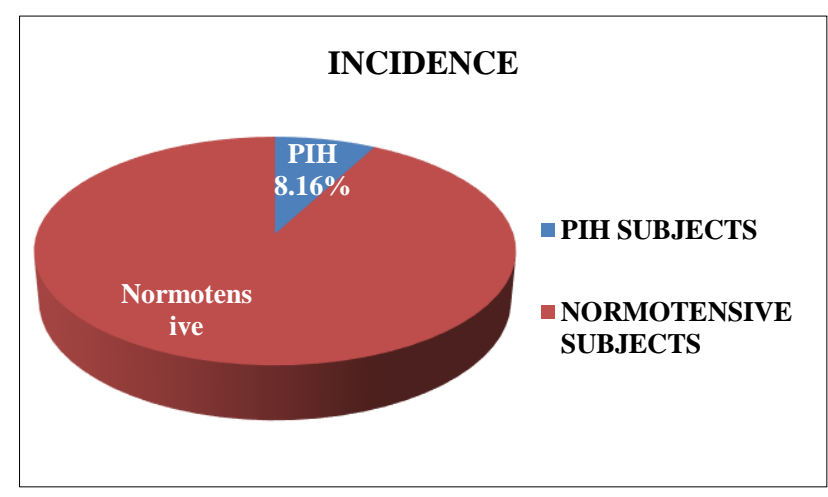

Figure 1: Incidence of PIH.

Table 1: Socio-demographic profile of patients with PIH.

\begin{tabular}{|llll|}
\hline \multirow{2}{*}{ Variables } & Parameters & $\begin{array}{c}\text { No. of } \\
\text { cases }\end{array}$ & Percentage \\
\hline \multirow{5}{*}{ Religion } & Rural & 56 & $70 \%$ \\
\cline { 2 - 4 } & Urban & 24 & $30 \%$ \\
\hline & Hindu & 66 & $82.5 \%$ \\
\cline { 2 - 4 } & Muslim & 13 & $16.25 \%$ \\
\cline { 2 - 4 } & Sikh & 01 & $1.25 \%$ \\
\cline { 2 - 4 } & Christian & - & - \\
\hline \multirow{3}{*}{$\begin{array}{l}\text { Educational } \\
\text { status }\end{array}$} & Illiterate & 41 & $51.25 \%$ \\
\cline { 2 - 4 } & $\begin{array}{l}\text { Up to } 8^{\text {th }} \\
\text { standard }\end{array}$ & 17 & $21.25 \%$ \\
\cline { 2 - 4 } & $9^{\text {th }}-10^{\text {th }}$ & 09 & $11.25 \%$ \\
\cline { 2 - 4 } & $11^{\text {th }}-12^{\text {th }}$ & 07 & $8.75 \%$ \\
\cline { 2 - 4 } & Graduation & 05 & $6.25 \%$ \\
\cline { 2 - 4 } & $\begin{array}{l}\text { Post- } \\
\text { graduation }\end{array}$ & 01 & $1.25 \%$ \\
\hline $\begin{array}{l}\text { Monthly income } \\
\text { (INR/month) }\end{array}$ & $<5000$ & 55 & $68.75 \%$ \\
\cline { 2 - 4 } & $>5000$ & 25 & $31.25 \%$ \\
\hline
\end{tabular}


Majority of the study subjects were rural dweller. Out of 80 study subjects 56 were from rural area $(70 \%)$ and 24 from urban area $(30 \%)$. Overall Hindu constituted the major chunk of the study subjects $(82.5 \%)$ and Muslim ranked the second $(16.25 \%)$. Study observed the higher incidence of PIH among illiterate women $(51.25 \%)$ and there was a decreasing trend of incidence among the women with higher education level. A higher incidence of PIH was also noted among the women of low-income group.

Table 2: Gestational age at which the cases were admitted $(n=80)$.

\begin{tabular}{|lll|}
\hline Gestational age & No. of cases & Percentage \\
\hline Preterm & 26 & $32.5 \%$ \\
\hline Term & 48 & $60 \%$ \\
\hline Post-term & 6 & $7.5 \%$ \\
\hline
\end{tabular}

Table 3: Incidence of PIH according to age $(n=80)$.

\begin{tabular}{|lll|}
\hline Age distribution & No. of cases & Percentage \\
\hline $19-24$ & 20 & $25 \%$ \\
\hline $25-30$ & 43 & $53.75 \%$ \\
\hline $31-35$ & 15 & $18.75 \%$ \\
\hline $36-40$ & 02 & $2.5 \%$ \\
\hline
\end{tabular}

Out of 80 cases of PIH studied in this study, the gestational age at the time of admission varied. $60 \%$ cases admitted to labour room were at term, $32.5 \%$ cases admitted were preterm and $7.5 \%$ cases were post-dated.

Table 4: Distribution according to parity $(n=80)$.

\begin{tabular}{|lll|}
\hline Parity & No. of cases & Percentage \\
\hline Primigravida & 54 & $67.5 \%$ \\
\hline Multigravida & 26 & $32.5 \%$ \\
\hline
\end{tabular}

Table 5: Mode of delivery $(n=80)$.

\begin{tabular}{|llllll|}
\hline $\begin{array}{l}\text { Distribution according to } \\
\text { gestational age }\end{array}$ & No. of cases & Caesarean section & Percentage & Vaginal delivery & Percentage \\
\hline Preterm & 26 & 16 & $61.53 \%$ & 10 & $38.46 \%$ \\
\hline Term & 48 & 39 & $81.25 \%$ & 09 & $18.75 \%$ \\
\hline Postdated & 06 & 04 & $66.6 \%$ & 02 & $33.33 \%$ \\
\hline Total & $\mathbf{8 0}$ & $\mathbf{5 9}$ & $\mathbf{7 3 . 7 5 \%}$ & $\mathbf{2 1}$ & $\mathbf{2 6 . 2 5 \%}$ \\
\hline
\end{tabular}

The distribution of PIH patients in respect to age group shows $53.75 \%$ were in the age group of 25-30 years and $25 \%$ were in age group of $19-24$ years. $18.75 \%$ cases were in the age group of 31-35 years and least were in the age group of $36-40$ with only $2.5 \%$.

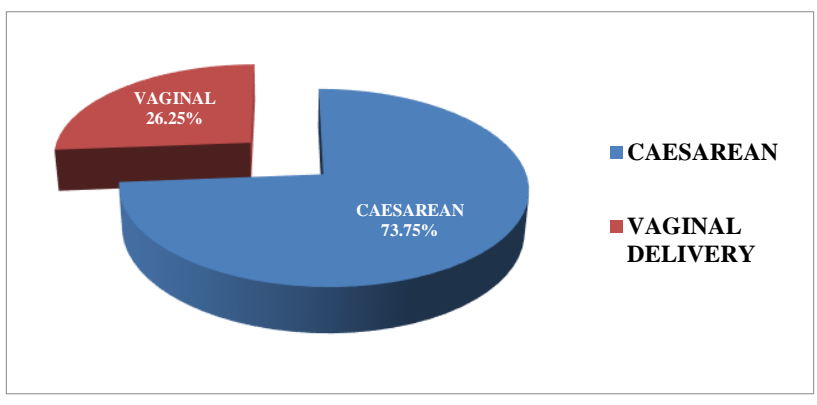

Figure 2: Mode of delivery.

In the present study, the incidence of pregnancy induced hypertension was found to be highest among primigravida. Out of the 80 cases studied, 54 were primigravida $(67.5 \%)$ and 26 were multigravida $(32.5 \%)$.

The mode of delivery of 80 cases were studied. Out of 80 cases, 59 cases delivered by caesarean section $(73.75 \%)$ and 21 cases delivered by vaginal delivery $(26.25 \%)$. The caesarean rate is $81.25 \%$ among the term patients and
$66.6 \%$ among the post-dated ones and $61.53 \%$ among preterm cases. Vaginal delivery rate was found to be $38.46 \%$ among preterm, $18.75 \%$ among term and $33.33 \%$ among post-dated.

Table 6: Complications.

\begin{tabular}{|lll|}
\hline Symptoms & No. of cases & Percentage \\
\hline Eclampsia & 13 & $16.25 \%$ \\
\hline Severe PIH & 10 & $12.5 \%$ \\
\hline Abruptio placentae & 2 & $2.5 \%$ \\
\hline HELLP syndrome & 1 & $1.25 \%$ \\
\hline Blindness & 0 & $0 \%$ \\
\hline
\end{tabular}

The complications were studied in form of cases developing eclampsia, abruptio placentae, HELLP Syndrome, severe PIH and blindness. Out of 80 cases 13 cases $(16.25 \%)$. were admitted with eclampsia. ${ }^{10}$ cases were with severe PIH (12.5\%). Abruptio placentae was seen in 2 cases $(2.5 \%)$. One case $(1.25 \%)$ was admitted with HELLP syndrome. Blindness was not seen in any case.

\section{DISCUSSION}

The incidence of PIH in this study was $8.16 \%$. The incidence of PIH ranges from in different countries as 
$1.5 \%$ in Sweden as compared to $7.5 \%$ in Brazil. ${ }^{15}$ This difference in incidence can be due to racial factors, age, parity or can be attributed to socioeconomic status. A study done by American Society of Nephrology states that women in rural areas have increased incidence of PIH. ${ }^{16}$ In a study done by Sachdeva et al, the incidence was found to be higher in rural setup. ${ }^{17}$ Factors like poverty, illiteracy, poor availability of health care facilities and lack of awareness among the general population attributes to high incidence among rural population.

In this study, majority of PIH cases were in age group of 25-30 years $(53.75 \%$.). In a study by Saxena $\mathrm{S}$ et al, a majority of cases were in age group of 21-25 years age group. ${ }^{18}$ In another study by Parmar MR et al, also majority of cases were in age group of 21- 25 years. ${ }^{19}$ Therefore it can be concluded from these studies that young maternal age is a significant risk factor for developing of PIH. In this country, where girls are married earlier especially in rural populations, therefore the incidence is higher in young age group.

In this study, majority of cases admitted with $\mathrm{PIH}$ were primigravida $(67.5 \%)$. In a retrospective study conducted in southeast Nigeria by Umegbolu EI et al, the incidence of PIH was higher among nulliparous women $(7.7 \%)$ as compared to $(5.5 \%)$ in multiparous women. ${ }^{20}$ In a study by Saxena $\mathrm{S}$ et al, also the majority of cases were primigravida (57\%). ${ }^{17}$ Sibai and Cunningham in their world-wide study has also found the incidence of PIH to be higher in nulliparous population. ${ }^{5}$ This study findings correlates with study by Irinyenikan et al, where most of the cases of PIH belonged to primigravida and also study by Sandhya et al, which stated in their study $60 \%$ cases were primigravida. $^{21,22}$

Majority of cases in this study were delivered by caesarean section $(73.75 \%)$. In the study by Parmar MR et al, LSCS incidence was found to be $17 \% .{ }^{17}$ Sivakumar $\mathrm{S}$ et al, has also found a higher incidence of $\mathrm{LSCS}^{22}$

In the present study, majority of delivered cases were term $(60 \%)$ and $(32.5 \%)$ had preterm delivery which was quite opposite of study by Parmar MR et al, where only $42 \%$ were term and $57 \%$ were preterm. ${ }^{19}$ Majority of preterm were delivered by caesarean section $(61.53 \%) .{ }^{19}$

Eclampsia was the most common complication noted in the present study followed by Abruptio placentae and HELLP syndrome which was quite similar to study by Parmar et al, where also eclampsia was the commonest complication. Similar finding was also seen in a study by Bansal et al. ${ }^{18,23}$

\section{CONCLUSION}

In the present study, pregnancy induced hypertension was more prevalent in the young age group and the majority of patients were primi and had educational status less than graduation. Younger age and less education can be attributed to the age itself or due to inadequate antenatal care and lack of awareness regarding antenatal care due to less education of the patient. Assessment of risk factors would identify women in early pregnancy who are at high risk of preeclampsia. Proper antenatal monitoring and time to time hospital visit can help to prevent adverse outcomes of pregnancy induced hypertension. Healthcare professionals can assess each pregnant woman's risk of pre-eclampsia at her booking visit and should plan antenatal care as per patient requirement.

Although being a hospital based study, the results may not be applicable to population at large and it needs further study taking larger population to establish the statistical parameters.

\section{Funding: No funding sources \\ Conflict of interest: None declared}

Ethical approval: The study was approved by the Institutional Ethics Committee

\section{REFERENCES}

1. Dunn P. Major ethical problems confronting perinatal care around the world. Int $\mathbf{J}$ Gynaecol Obstet. 1995;5:205-10.

2. New York State Department of Health. Hypertensive disorders in pregnancy: guideline summary, 2013. Available at: https://www.health.ny.gov/hypertensive disorders/2013_hdp_guideline. Accessed 12 July 2016.

3. Krishnachetty B, Plaat F. Management of hypertensive disorders of pregnancy. Anaest Tut Week. 2014;304:1-13.

4. Sibai BM. Diagnosis and management of gestational hypertension and preeclampsia. Obst Gyn. 2003;102(1):181-92.

5. Sibai BM, Cunningham FG. Prevention of preeclampsia and eclampsia. In Lindheimer MD, Roberts JM, Cunningham FG editors; Chesley's Hypertensive Disorders of Pregnancy. $3^{\text {rd }}$ edition, Elsevier, New York; 2009:215.

6. Douglas KA, Redman CWG; Eclampsia in the United Kingdom. Br Med J. 1994;309:1395-400.

7. World Health Organization; International collaborative study of hypertensive disorders of pregnancy. Geographic variation in the incidence of hypertension in pregnancy. Am J Obstet Gynecol. 1988;158(1):80-3.

8. Crowther CA. Eclampsia at Harare maternity hospital. An epidemiological study. S Afr Med. 1985;68(13):927-9.

9. Bergstrom S, Povey G, Songane F, Ching C; Seasonal incidence of eclampsia and its relationship to metereological data in Mozambique. J Perinat Med. 1992;20(2):153-8.

10. Dutta DC; Text book of obstetrics. $3^{\text {rd }}$ edition, New Central Book Agency (Pvt) Ltd., Calcutta; 1995:230236. 
11. ACOG; Diagnosis and Management of Preeclampsia and Eclampsia. ACOG Practice Bulletin, No 33; 2002.

12. World Health Organization, 1998. The World health report: 1998: Life in the $21^{\text {st }}$ century: a vision for all: executive summary (No. WHO/WHR/98.1). Geneva: World Health Organization.

13. Parmar MT, Solanki HM, Gosalia VV. Study of risk factors of perinatal death in pregnancy induced hypertension (PIH). Nat J Com Med. 2012;3(4):7037.

14. Chesley LC, Annitto JE, Cosgrove RA. The familial factor in toxemia of pregnancy. Obstet Gynecol. 1968;32(3):303.

15. Report of the National high blood pressure education program working group on high blood pressure in pregnancy. Am J Obstet Gynecol. 2000;183(1):S1S22.

16. American Society of Nephrology; News release, 2008. Available at: http://www.wrongdiagnosis.com/hd/news/62113 8.pregnant-rural-womenmore-at-risk.htm. Accessed on $13^{\text {th }}$ February 2020.

17. Sachdeva PD, Patel BG, Bhatt MV. A study of incidence and management of pregnancy induced hypertension in Central Gujarat, India. Inter J Univer Pharma Life Sci. 2011;1(3):61-70.

18. Saxena S, Srivastava PC, Thimmaraju KV, Mallick AK, Dalmia K, Das B. Socio-demographic profile of pregnancy induced hypertension in a tertiary care centre. Religion. 2014;47(67.14):51.

19. Jena P, Mohapatra S. A retrospective study of sociodemographic factors in pregnancy induced hypertension in a tertiary care hospital in eastern India. Inter J Clin Obstet Gynaecol. 2019;3(1):78-81.

20. Umegbolu EI, Ogamba JO. Incidence of gestational hypertension among pregnant women (2006-2015) in Enugu State, Southeast Nigeria: a retrospective study. Inter $\mathbf{J}$ Comm Med Pub Health. 2017;4(2):357.

21. Irinyenikan TA, Olumuyiwa Adebola Roberts OA, Arowojolu A. Serum lipid levels in pregnant normotensive and gestational hypertensive women in Ibadan, Nigeria. Ann Biol Res. 2013;4(4):204-8.

22. Sandhya S, Bhat BV, Badhe BA. Effect of pregnancy induced hypertension on mothers and their babies. Ind J Pediatr. 2007;74(7):27-9.

23. Bansal D, Deodhar P. A clinical study of maternal and perinatal outcome in oligohydramnios. J Res Med Den Sci. 2015;3(4):312-6.

Cite this article as: Bairwa R, Mandve S, Sharma S. Study of socio-demographic factors in cases of pregnancy induced hypertension and its associated risk factors in a tertiary care hospital. Int J Reprod Contracept Obstet Gynecol 2020;9:1842-6. 